\title{
BUKU CERITA SEBAGAI MEDIA PENDIDIKAN KARAKTER ANAK DI DUSUN TEMBEN
}

\author{
Elisabeth Desiana Mayasari 1,*, Silverio R. L. Aji Sampurno², Natanael Kristiyono Wibowo ${ }^{3}$, \\ Maria Mellinia Tri Hastuti ${ }^{4}$,Tasyia Juliana Sunardi ${ }^{5}$ \\ 1,2,3,4,5 Universitas Sanata Dharma \\ ЛL Gejayan, Mrican Tromolpos 29, 55002, Mrican, Caturtunggal, Kec. Depok, Kabupaten Sleman, Daerah \\ Istimewa Yogyakarta 55281 \\ *Penulis korespondensi; email: elisabethmayasari@gmail.com
}

\begin{abstract}
Abstrak: Pandemi Covid-19 menempatkan pembelajaran dari sekolah ke rumah, sehingga membuat proses penanaman pendidikan karakter yang sebelumnya dilakukan oleh guru mengalami kendala. Permasalahan serupa pun dialami oleh anak-anak di Dusun Temben, Desa Ngentakrejo, Kecamatan Lendah, Kabupaten Kulon Progo yang harus belajar dari rumah selama masa pandemi. Pada proses mendapatkan kepribadian yang holistik, diperlukan karakter yang melekat pada pribadi seseorang. Kegiatan pengabdian masyarakat ini bertujuan mendampingi anak dengan membaca buku cerita sebagai media pendidikan karakter anak di Dusun Temben, Desa Ngentakrejo, Kecamatan Lendah, Kabupaten Kulon Progo. Metode kegiatan pengabdian ini adalah pengabdi menggunakan observasi dan wawancara mengenai karakter yang perlu mendapatkan pendampingan pada anak, kemudian melakukan analisis dan membuat rekomendasi karakter yang akan dibentuk bersama anak. Setelah melakukan pendampingan, pengabdi melakukan kegiatan observasi wawancara akhir. Kemudian dilanjutkan dengan refleksi bersama mengenai karakter anak yang telah terbentuk. Kesimpulan dari kegiatan pengabdian ini adalah 1) Anak-anak dapat menumbuhkan karakter berani mencoba hal baru, 2) Anak-anak dapat menumbuhkan karakter cinta terhadap makhluk hidup, 3) Anak-anak dapat menumbuhkan karakter kekeluargaan sehingga muncul perasaan ingin membantu dan bekerja sama dalam lingkungan keluarga, 4) Anak-anak dapat menumbuhkan karakter bertanggung jawab untuk menjaga kebersihan diri dan lingkungan demi kesehatan bersama, 5) Anak-anak dapat menumbuhkan karakter mandiri dan mengenal diri sendiri terlihat dari partisipasi anak-anak mengikuti setiap kegiatan sehingga anak-anak dapat belajar menjadi mandiri dan memahami hal-hal yang terjadi pada diri mereka sendiri.
\end{abstract}

Kata kunci: Buku cerita, karakter, anak.

Abstract: The Covid-19 pandemic places learning from school to home, thus making the process of planting character education previously carried out by teachers experiencing obstacles. Children experienced similar problems in Temben Hamlet, Ngentakrejo Village, Lendah District, Kulon Progo Regency, who had to learn from home during the pandemic. In getting a holistic personality, it is necessary to have a character that is inherent in a person's personality. This community service activity aims to assist children by reading storybooks as a medium for character education for children in Temben Hamlet, Ngentakrejo Village, Lendah District, Kulon Progo Regency. The method of this service activity is that the servant uses observations and interviews about the characters who need assistance to the child, then analyzes and makes recommendations for the character to be formed with the child. After assisting, the servant conducts observations of the final interview. Then proceed with a joint reflection on the character of the child that has been formed. The conclusion of this service activity is 1) Children can grow the character to dare to try new things, 2) Children can grow the character of love for living things, 3) Children can develop a family character to feel like helping and working together in a family environment, 4) Children can develop the character of being responsible for maintaining personal and environmental hygiene for joint health, 5) Children can develop independent characters and know themselves to be seen. Based on the participation of children following every activity to learn to be independent and understand what happens to themselves.

Keywords: Storybook, character, children. 


\section{PENDAHULUAN}

Fokus kebijakan pendidikan pada kurikulum 2013 mengarah pada kecakapan abad 21, yaitu literasi, kompetensi, dan karakter. Guna melaksanakan pendidikan karakter pada kurikulum 2013, pemerintah menyelenggarakan Gerakan Penguatan Pendidikan Karakter (PPK). Berdasarkan Peraturan Presiden Nomor 87 tahun 2017, PPK merupakan gerakan pendidikan untuk memperkuat karakter peserta didik melalui harmonisasi olah hati, olah rasa, olah pikir, dan olah raga di bawah tanggung jawab satuan pendidikan, yakni sekolah dengan pelibatan dan kerja sama antara sekolah, keluarga, dan masyarakat. Pada pasal 3 Peraturan Presiden Nomor 87 tahun 2017, menyatakan bahwa terdapat lima karakter utama menjadi prioritas pengembangan PPK, yaitu religius, nasionalisme, integritas, mandiri, dan gotong royong.

Karakter-karakter tersebut merupakan suatu proses pendidikan yang holistik sehingga dapat mengaitkan dimensi moral dengan ranah sosial dalam kehidupan peserta didik sehingga terbentuk generasi yang berkualitas (Kurniawan, 2013). Menurut Kurniawan (2013), pendidikan karakter bertujuan untuk mewujudkan nilai-nilai keyakinan masyarakat sebagai kekuatan moral dalam kehidupan melalui kejujuran, amanah, disiplin dan kerjasama. Pada program pengajaran pun perlu adanya rencana yang menumbuhkembangkan karakter siswa yang menekankan pada ranah emosional tanpa meninggalkan ranah kognitif dan area keterampilan.

Pendidikan karakter juga merupakan sebuah proses transformasi nilai kehidupan yang berkembang dalam kepribadian seseorang kemudian melebur menjadi perilaku orang itu (Kesuma, Triatna, \& Permana, 2011). Pada konteks sekolah, pendidikan karakter diimplementasikan melalui tatap muka disertai contoh dan diskusi antara guru dan anak. Namun, pandemi Covid-19 yang memindah pembelajaran dari sekolah ke rumah, membuat proses penanaman pendidikan karakter oleh guru menjadi mengalami kendala (Nur, 2020).

Selain tidak ada pembimbingan secara langsung dari guru, permasalahan semakin bertambah yaitu 1) ketidakdisiplinan anak dalam mengisi daftar hadir online, 2) anak tidak aktif mengikuti diskusi dalam grup WhatsApp, 3) adanya tindakan tidak jujur dalam kegiatan belajar. Berbagai permasalahan ini menjadi sinyal buruk dalam pendidikan karakter di masa pandemi (Wardana, 2020).

Permasalahan serupa pun dialami oleh anakanak di Dusun Temben, Desa Ngentakrejo, Kecamatan Lendah, Kabupaten Kulon Progo yang harus belajar dari rumah selama masa pandemi. Pada proses pembelajaran yang mereka alami, sasaran materi lebih mencakup pada aspek kognitif saja. Padahal untuk mendapatkan kepribadian yang holistik, diperlukan aspek afektif dan psikomotorik juga. Pendidikan karakter melekat pada pribadi seseorang merupakan wujud dari internalisasi landasan berpikir dan berperilaku yang memunculkan suatu ciri khas pada individu tersebut. Pendidikan dapat membentuk dan menguatkan karakter individu untuk berkembang dengan baik (Maunah, 2015).

Pendidikan mengenai karakter dapat diberikan secara konkrit menggunakan buku cerita. Buku cerita anak merupakan salah satu bentuk dari genre fiksi sastra anak, yang mempunyai tema persoalan kehidupan manusia (Nurgiyantoro, 2016). Menurut Nurgiyantoro (2016), buku cerita memiliki berbagai fungsi, yaitu membantu siswa untuk belajar tentang kehidupan masyarakat secara konkret lewat kata-kata maupun gambar ilustrasi. Selain itu, karya sastra yang tertuang dalam buku cerita mempunyai nilai-nilai pendidikan moral yang berguna untuk menanamkan pendidikan karakter (Wibowo, 2013).

Selain itu, buku cerita bergambar bagi anak juga berfungsi sebagai 1) mengembangkan emosi anak, 2) menjadi jembatan untuk mempelajari tentang dunia, dan membawa anak pada situasi nyata di tengah masyarakat serta alam 3) memampukan anak untuk belajar dari orang lain 4) menggali kesenangan dalam diri anak 5) mensyukuri dan mengapresiasi keindahan dan 6) merupakan stimulus dalam imajinasi anak (Mitchel, 2003).

Berdasarkan data yang diambil pada bulan Juli 2021 di Dusun Temben, Desa Ngentakrejo, Kecamatan Lendah, Kabupaten Kulon Progo dengan menggunakan observasi dan juga wawancara menunjukkan bahwa (1) kurang tersedianya tempat dan sumber bacaan bagi anak, (2) kemampuan anak untuk membaca cukup baik, (3) kurang tersedianya buku bacaan untuk menumbuhkan pendidikan karakter bagi anak, (4) anak-anak lebih cenderung bermain gadget setelah melakukan kegiatan sekolah dan (5) keinginan anak untuk membaca buku sangat rendah, hal tersebut dapat dilihat ketika mereka malas untuk membaca saat mengikuti kegiatan membaca.

Berdasarkan urgensi dari permasalahan di Dusun Temben, Desa Ngentakrejo, Kecamatan Lendah, Kabupaten Kulon Progo saat berada disituasi pandemi dan pendidikan karakter maka perlu dilakukan pendampingan karakter anak dengan menggunakan media buku cerita. Hal tersebut akan berguna untuk menanamkan karakter baik pada anak dan melakukan langkah-langkah preventif mengenai karakter secara jangka panjang. Sasaran kegiatan dari pengabdian masyarakat ini adalah anak berusia SD di di Dusun Temben, 
Desa Ngentakrejo, Kecamatan Lendah, Kabupaten Kulon Progo. Kegiatan pengabdian masyarakat ini bertujuan mendampingi anak dengan membaca buku cerita sebagai media pendidikan karakter anak di Dusun Temben, Desa Ngentakrejo, Kecamatan Lendah, Kabupaten Kulon Progo.

Urgensi dan signifikansi pendampingan kegiatan "Buku Cerita Sebagai Media Pendidikan Karakter Anak di Dusun Temben" adalah: 1) Anak perlu mendapatkan pendampingan dalam pembentukan dan pengembangan potensi agar berpikiran, berhati dan berperilaku baik, 2) Anak perlu mendapatkan pendampingan dalam perbaikan dan penguatan karakter berani mencoba hal baru, cinta makhluk hidup, kekeluargaan, bertanggung jawab, mandiri, dan mengenal diri sendiri sebagai wujud pendidikan di keluarga, sekolah, dan masyarakat, 3) Anak perlu mendapatkan pendampingan untuk menjadi peka dalam menyerap nilai-nilai baik yang diajarkan.

Selain urgensi dan signifikansi, kegiatan pengabdian masyarakat ini mempunyai manfaat: 1) Anak mendapatkan pendampingan dalam pembentukan dan pengembangan potensi agar berpikiran, berhati dan berperilaku baik, 2) Anak mendapatkan pendampingan dalam perbaikan dan penguatan karakter berani mencoba hal baru, cinta makhluk hidup, kekeluargaan, bertanggung jawab, mandiri, dan mengenal diri sendiri sebagai wujud pendidikan di keluarga, sekolah, dan masyarakat, 3) Anak mendapatkan pendampingan untuk menjadi peka dalam menyerap nilai-nilai baik yang diajarkan.

\section{METODE PELAKSANAAN}

\section{Waktu dan Tempat Kegiatan}

Kegiatan ini berlangsung pada bulan Juni dan Juli 2021. Kegiatan pengabdian akan dilakukan secara daring dan luring dengan menggunakan protokol kesehatan. Sasaran kegiatan ini adalah dengan sasarannya anak-anak di Dusun Temben, Desa Ngentakrejo, Kecamatan Lendah, Kabupaten Kulon Progo.

\section{Metode Pelaksanaan Kegiatan}

Metode pelaksanaan kegiatan pengabdian masyarakat yang berjudul "Buku Cerita Sebagai Media Pendidikan Karakter Anak di Dusun Temben, Desa Ngentakrejo, Kecamatan Lendah, Kabupaten Kulon Progo" yaitu:

1. Pengabdi menggunakan observasi dan wawancara mengenai karakter yang perlu mendapatkan pendampingan pada anak.

2. Setelah data terkumpul, pengabdi melakukan analisis kemudian membuat rekomendasi karakter yang akan dibentuk bersama anak.
3. Karakter pada diri anak yang memerlukan perhatian ini akan didiskusikan bersama anak melalui media buku cerita dan metode pendampingan lainnya. Kegiatan ini akan dibagi dalam sepuluh sesi. Seluruh sesi akan dilakukan secara daring dan luring dengan protokol kesehatan yang baik.

4. Pada setiap sesinya, anak akan melakukan kegiatan membaca buku diawal kegiatan dan kegiatan membaca ini dilakukan selama 2 minggu. Pada minggu berikutnya, anak dan pendamping akan mendiskusikannya secara bersama-sama. Kemudian pada minggu berikutnya dan seterusnya anak-anak akan berkegiatan sesuai dengan program yang sudah disiapkan.

5. Setelah melakukan pendampingan, pengabdi melakukan kegiatan observasi wawancara akhir serta refleksi bersama mengenai karakter anak yang telah terbentuk.

\section{Instrumen}

Pengabdi menggunakan instrumen yang disusun berdasarkan analisis kebutuhan yang dilakukan di lapangan. Instrumen yang digunakan adalah panduan observasi dan wawancara. Pengambilan data dilakukan secara daring dan luring kepada anak. Selain instrumen, data juga akan didapatkan dari refleksi anak mengenai karakter yang ditemukan dari buku cerita yang mereka baca dan dari film yang telah mereka lihat. Kegiatan refleksi ini dilaksanakan pada akhir kegiatan sehingga anak-anak dapat mengendapkan apa yang telah mereka lakukan pada hari itu. Hasil yang didapatkan akan dianalisis sebagai keberhasilan program yang sudah dijalankan oleh pengabdi.

\section{HASIL DAN PEMBAHASAN}

Hasil dari kegiatan pengabdian masyarakat yang berjudul "Buku Cerita Sebagai Media Pendidikan Karakter Anak di Dusun Temben" ini yaitu:

\section{Kegiatan Mencoba Hal Baru}

Kegiatan yang dilakukan untuk menumbuhkan karakter berani mencoba hal baru yang dimiliki oleh anak-anak adalah dengan melakukan program kegiatan membaca dan menulis cerita pendek, membuat poster terkait dengan kesehatan, dan melakukan kegiatan membuat handsanitizer secara mandiri. Dalam kegiatan membaca dan menulis cerpen ini, anak-anak dapat menumbuhkan karakter berani mencoba hal baru melalui tugas membuat cerita pendek setelah mereka membaca buku bacaan dan menyebutkan pesan moral yang terdapat pada buku bacaan tersebut. 
Sedangkan, untuk menunjukan karakter berani mencoba hal baru anak-anak melakukan kegiatan membuat poster tentang kesehatan serta membuat handsanitizer secara mandiri. Karakter berani mencoba hal baru ini, ditunjukan dengan anakanak mau mencoba membuat poster dengan menggunakan alat bantu selain dengan menggambar secara manual dan dalam kegiatan membuat handsanitizer ini anak-anak dapat memperhatikan dengan seksama penjelasan yang diberikan dan dapat memahami pentingnya penggunaan handsanitizer disaat keadaan yang sekarang ini. Materi ini dibawakan dengan santai sehingga anak-anak dapat mengerti materi yang sedang diberikan dan mereka bisa menerapkannya di keseharian mereka. Berikut gambar-gambar kegiatan yang telah dilakukan.

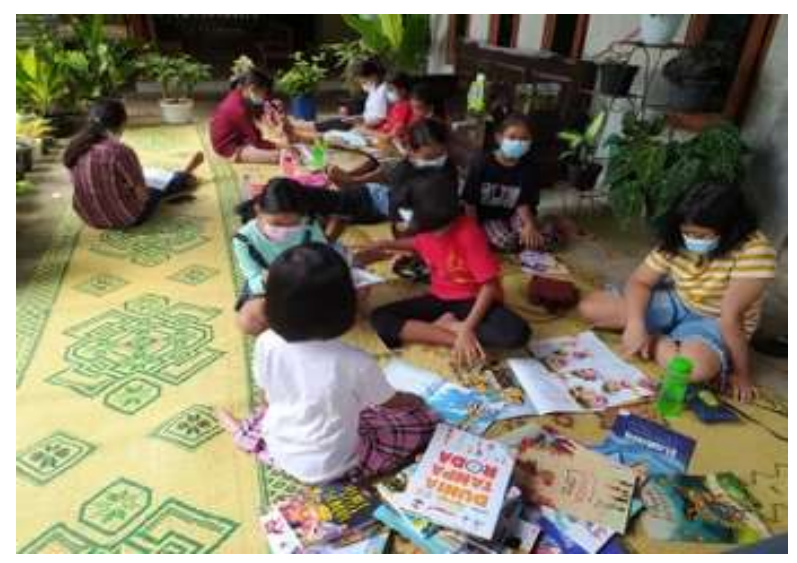

Gambar 1. Anak membuat poster

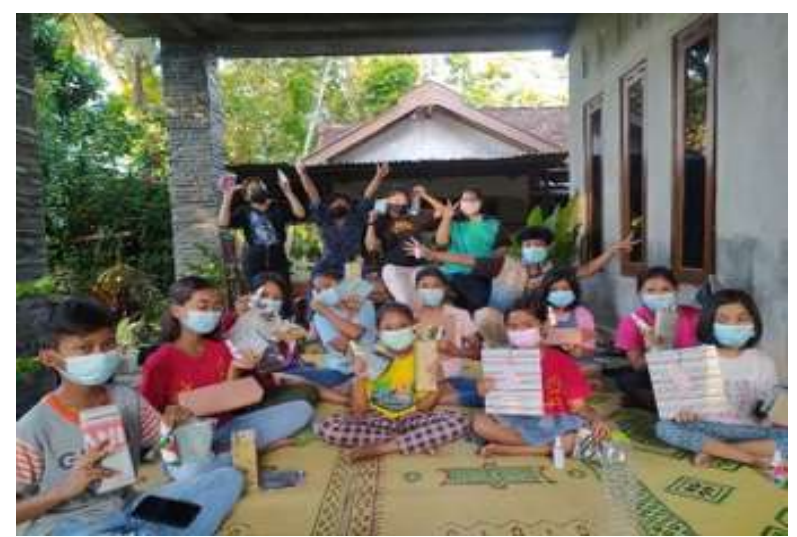

Gambar 2. Anak menunjukan hasil karya poster

Berdasarkan dari wawancara dan juga observasi sebelum melaksanakan kegiatan tersebut, pelaksana kegiatan mendapatkan data bahwa anak-anak belum cukup tertarik kepada kegiatan yang berkaitan dengan literasi membaca serta belum menunjukan secara langsung karakter berani mencoba hal baru di dalam kehidupan seharihari. Dari data yang didapatkan anak-anak lebih cenderung menghindari kegiatan yang belum pernah mereka ketahui atau mereka lakukan, seperti membuat sesuatu dengan alat bantu berupa aplikasi ataupun laptop. Selain itu juga anak-anak cenderung mudah bosan dan tidak terlalu tertarik dengan kegiatan yang berhubungan dengan membaca. Berdasarkan data diatas maka pelaksana membuat beberapa program kegiatan untuk melihat apakah terjadi perubahan atau peningkatan pada anak. Setelah melaksanakan program kegiatan ini, pelakasana melakukan pengumpulan data melalui wawancara dan juga observasi. Setelah dilakukannya wawancara dan juga observasi, pelaksana program dapat menyimpulkan jika anakanak mulai bisa untuk menumbuhkan karakter berani mencoba hal baru. Hal tersebut dapat dilihat dari partisipasi anak-anak dengan mengikuti setiap kegiatan yang sudah dirancang oleh pelaksana program dengan semangat, serta munculnya keinginan untuk berkegiatan mengenai hal yang baru dari anak. Berikut merupakan gambar poster hasil karya anak-anak.

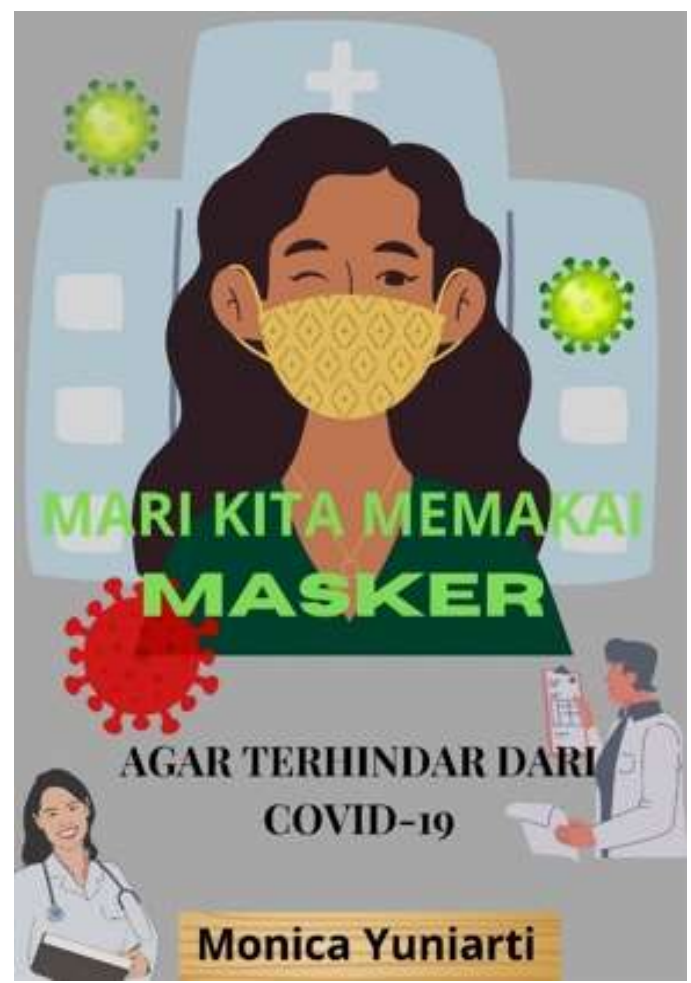

Gambar 3. Poster hasil karya anak

\section{Kegiatan Cinta Makhluk Hidup}

Kegiatan yang dilakukan untuk menumbuhkan karakter cinta makhluk hidup yang dimiliki pada anak adalah dengan adanya program kegiatan menanam tanaman dan melakukan kegiatan membaca buku cerita kemudian dilanjutkan dengan menonton film bersama. Pada saat kegiatan menanam sayuran dengan menggunakan media tanam polybag ini anak dapat menunjukkan sifat peduli terhadap makhluk hidup yang ada disekitar seperti tumbuh-tumbuhan dengan merawat 
tanaman sayur yang sudah mereka tanam sebelumnya. Pada saat kegiatan membaca buku cerita dan menonton film bersama, anak dapat menemukan serta mendalami makna serta menanamkan sikap cinta terhadap keluarga di kehidupan mereka sehari-hari. Berikut merupakan gambar-gambar kegiatan yang telah dilakukan,

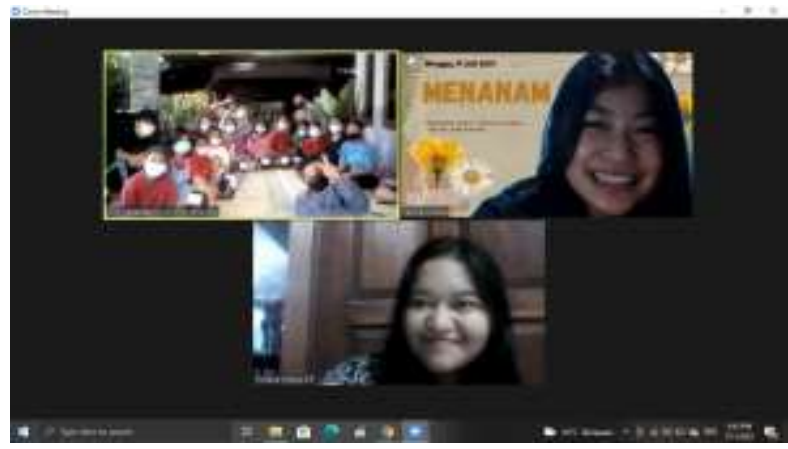

Gambar 4. Kegiatan secara daring

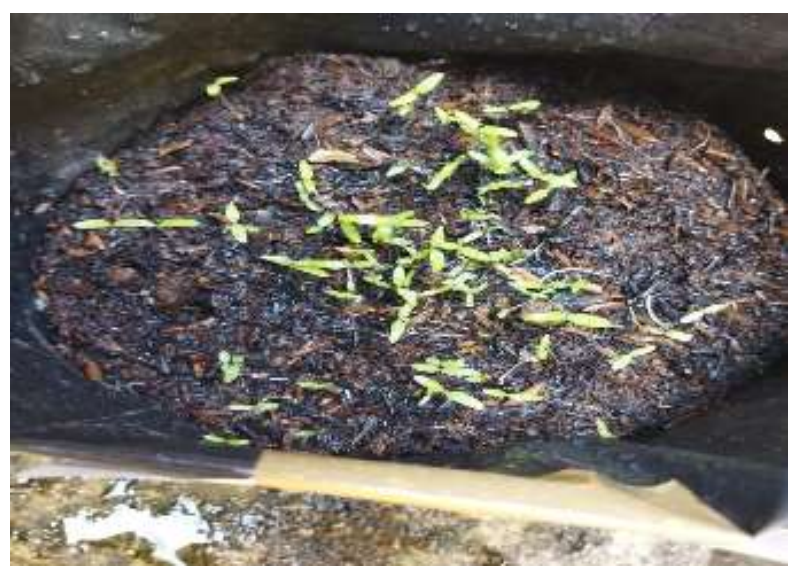

Gambar 5. Kegiatan menanam di polybag

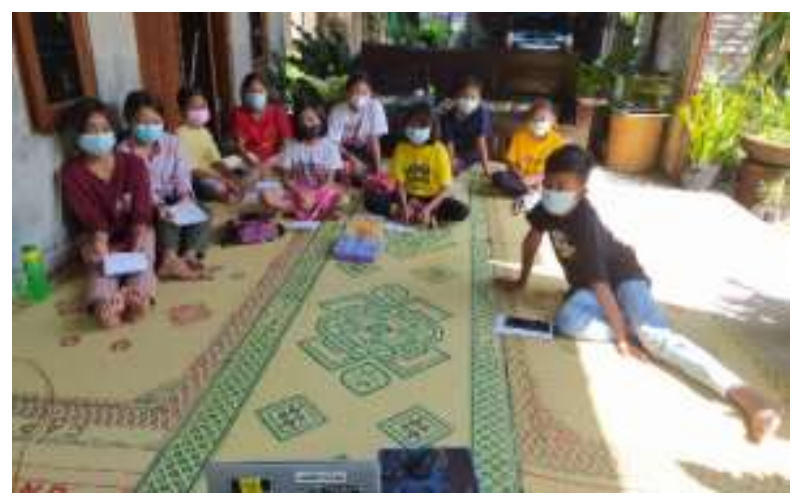

Gambar 6. Kegiatan menonton film

Berdasarkan dari wawancara dan juga observasi sebelum melaksanakan kegiatan tersebut, pengabdi mendapatkan data bahwa anak-anak belum bisa untuk mendalami karakter cinta terhadap makhluk hidup didalam kehidupan mereka sehari-hari. Dari data yang diambil oleh pelaksana program dapat dilihat juga anak-anak tersebut kurang peka mereka untuk mencintai tanaman yang ada disekitar mereka. Berdasarkan dari hasil wawancara dan observasi sebelum pelaksanaan program kegiatan, pelaksana program mendapatkan data jika anak-anak tersebut kurang suka untuk melakukan kegiatan literasi yang biasa mereka lakukan dengan cara menonton film. Setelah melaksanakan program kegiatan ini, telah dilakukan pengumpulan data melalui wawancara dan juga observasi. Setelah dilakukannya wawancara dan juga observasi, pelaksana program dapat menyimpulkan jika anak-anak mulai bisa untuk menumbuhkan karakter cinta terhadap makhluk hidup. Hal tersebut dapat dilihat dari partisipasi anak-anak yang baik pada kegiatan dan mereka merasa semakin menghargai tanaman dan hewan di sekitar mereka.

\section{Kegiatan Kekeluargaan}

Kegiatan yang dilakukan untuk menumbuhkan karakter kekeluargaan ini dengan adanya kegiatan menanam tanaman dan kegiatan literasi dengan membuat cerita pendek (cerpen) tentang sejarah dasar. Dalam kegiatan menanam, anakanak dapat bercengkrama dan memperhatikan ketika diberikan penjelasan, sehingga menumbuhkan karakter kekeluargaan. Sedangkan, karakter kekeluargaan dapat ditumbuhkan melalui kegiatan literasi cerpen sejarah dasar dengan materi sejarah keluarga. Sehingga anak-anak dapat mengenal silsilah keluarga masing-masing dan dapat membuka pecakapan dengan orang tua mereka di rumah. Materi ini dibawakan dengan menyenangkan sehingga anak-anak dapat mengerti materi yang sedang diberikan. Berikut merupakan gambar kegiatan yang telah dilakukan,

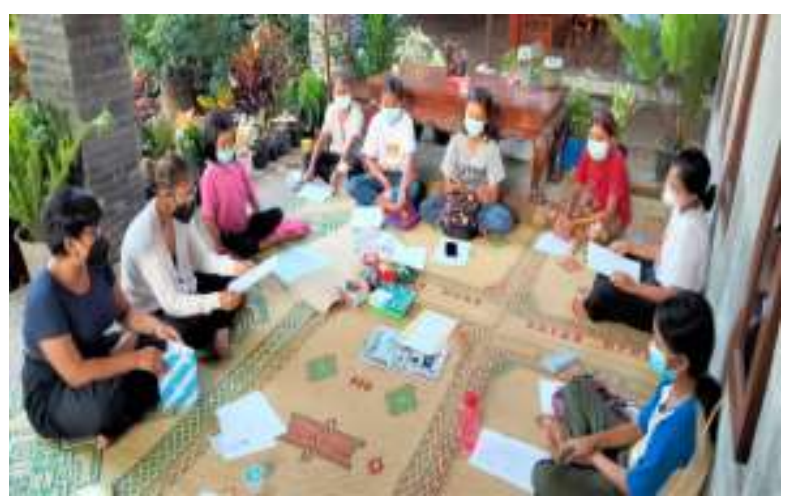

Gambar 7. Kegiatan membaca cerpen

Berdasarkan wawancara dan observasi sebelum melaksanakan kegiatan tersebut, data yang didapati bahwa anak-anak belum adanya karakter kekeluargaan dalam hal pengerjaan tugas sekolah dan kurangnya literasi yang didapat berkaitan dengan sejarah, termasuk sejarah keluarga. Data yang didapati juga anak-anak belum pernah membuat tentang sejarah silsilah keluarga mereka dan 
menanyakan kepada keluarga. Dengan adanya pelaksanakan literasi sejarah yang berkaitan dengan silsilah keluarga, anak-anak mulai mengenali keluarga mereka, dari mana keluarga mereka berasal dan pekerjaan yang dilakukan oleh keluarga mereka. Selain itu dengan adanya kegiatan menanam membuat rasa kekeluargaan semakin erat. Setelah kegiatan ini, telah dilaksanakan data melalui wawancara dan observasi didapati bahwa anak-anak dapat menumbuhkan karakter kekeluargaan sehingga muncul perasaan ingin membantu dan bekerja sama dalam lingkungan keluarga. Keinginan membantu ini dilihat dari sikap mereka yang mulai membantu pekerjaan rumah tangga yang sederhana.

\section{Kegiatan Bertanggung jawab}

Kegiatan yang dilakukan untuk menumbuhkan karakter bertangggung jawab ini yaitu mendongeng dan kegiatan lokakarya protokol kesehatan dengan praktik mencuci tangan yang benar. Dalam kegiatan mendongeng anak-anak dapat menumbuhkan karakter bertanggung jawabnya melalui tugas pembuatan video yang isinya anak mendongeng jenis fabel. Sedangkan, karakter bertanggung jawab yang ditumbuhkan dalam kegiatan lokakarya protokol kesehatan dengan mencuci tangan yang benar, anak-anak dapat memperhatikan saat kegiatan lokakarya sehingga dapat menjawab setiap pertanyaan dan berani mencoba untuk praktik mencuci tangan dengan benar melalui respon dari anak-anak dalam kegiatan ini anak-anak mulai ada karakter tanggung jawab setiap anaknya. Berikut merupakan gambar-gambar kegiatan yang telah dilakukan.

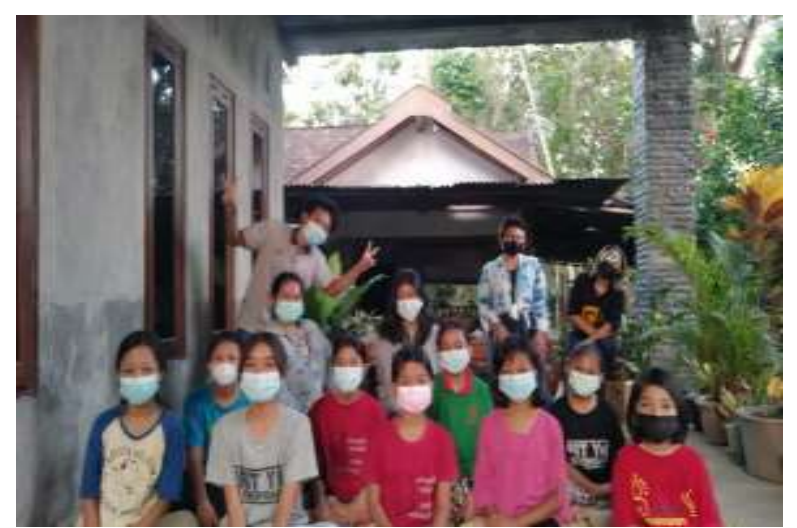

Gambar 8. Kegiatan mendongeng

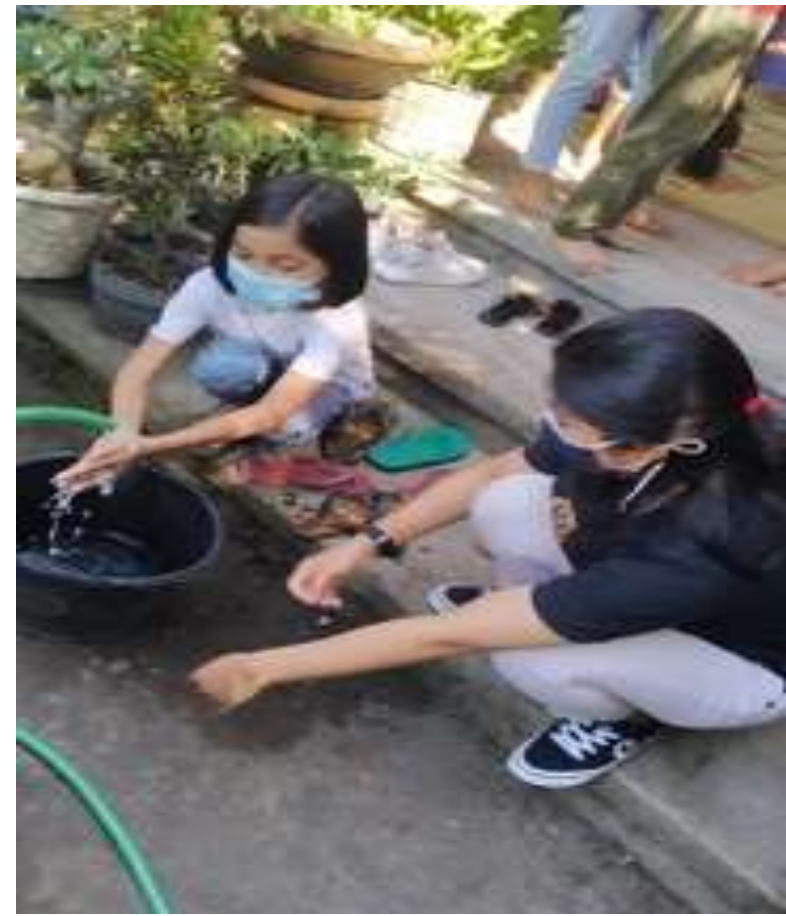

Gambar 9. Kegiatan mencuci tangan

Berdasarkan wawancara dan observasi sebelum melaksanakan kegiatan tersebut, data yang didapati bahwa anak-anak belum adanya karakter bertanggung jawab dalam hal pengerjaan tugas sekolah dan kurangnya literasi yang didapat berkaitan dengan dongeng. Data yang didapati juga anak-anak belum pernah praktik mendongeng dan hanya terdapat beberapa anak yang paham pengetahuan tentang dongeng. Dari adanya data seperti di atas, pelaksana membuat kegiatan mendongeng. Dalam pelaksanaan ini juga sedang dalam situasi pandemic covid-19 maka, diadakan kegiatan yang berkaitan dengan protokol kesehatan. Adapun kegiatan yang berkaitan dengan protokol Kesehatan yaitu kegiatan lokakarya dan praktik cara mencuci tangan yang benar. Pelaksana juga mengaitkan kegiatan tersebut dengan karakter yang perlu ditumbuhkan yaitu bertanggung jawab. Setelah kegiatan ini, telah dilaksanakan data melalui wawancara dan observasi didapati bahwa anak-anak mulai tumbuh karakter bertanggung jawab untuk menjaga kebersihan diri dan lingkungan demi kesehatan bersama terlihat dari partisipasi anak-anak mengikuti setiap kegiatan yang ada. Berikut merupakan gambar poster hasil karya anak-anak: 


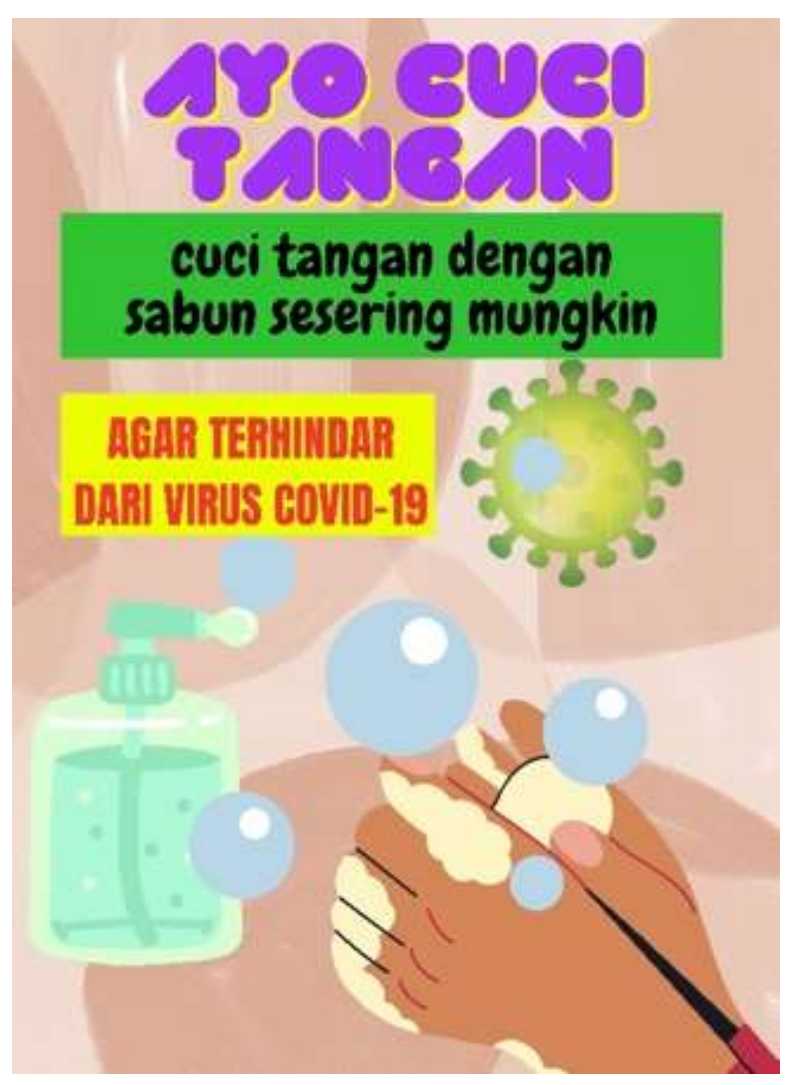

Gambar 10. Poster hasil karya anak

\section{Kegiatan Mandiri dan Mengenal diri sendiri}

Berdasarkan wawancara dan observasi sebelum melaksanakan kegiatan tersebut, anak-anak perlu memiliki karakter mandiri dari dalam diri mengenai menanam dan jenis tanaman rimpang. Selain itu, perlu adanya pengetahuan berkaitan dengan sejarah, termasuk sejarah Indonesia dan asal usulnya. Berdasarkan data yang didapat, anak-anak merasa tertarik dan ingin mengetahui sejarah besar Indonesia, asal usul daerah dan silsilah keluarganya.

Berkaitan dengan kebutuhan anak tersebut, kegiatan yang dilakukan untuk menumbuhkan sikap mengenal diri sendiri yaitu dengan kegiatan membaca buku cerita sejarah kemudian dilanjutkan dengan praktek menanam rimpang. Pada kegiatan membaca buku cerita sejarah, anak-anak diajak untuk mengenal diri sendiri dengan mengetahui asal usulnya, siapa mereka, serta mengetahui latar belakang dirinya sehingga ketika ditanya "kamu dari mana? kamu orang mana? Apa itu Indonesia? Apa itu pulau Jawa" mereka mampu menjawabnya. Selanjutnya dalam kegiatan menanam rimpang anak-anak diajak untuk memiliki karakter mandiri dengan belajar memperoleh sendiri hasil rimpang dalam memenuhi kebutuhan dapur sehingga tidak perlu beli apalagi di masa pandemi seperti ini sulit untuk keluar dan harga pangan meningkat. Berikut merupakan gambargamnbar kegiatan yang telah dilakukan:

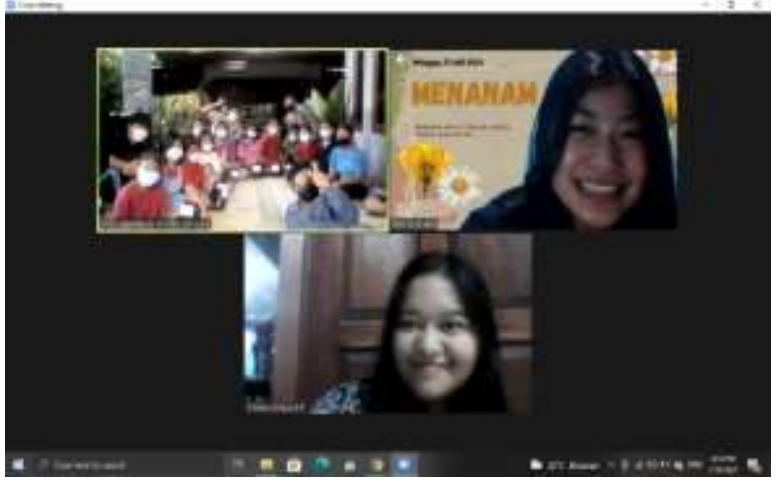

Gambar 11. Kegiatan secara daring

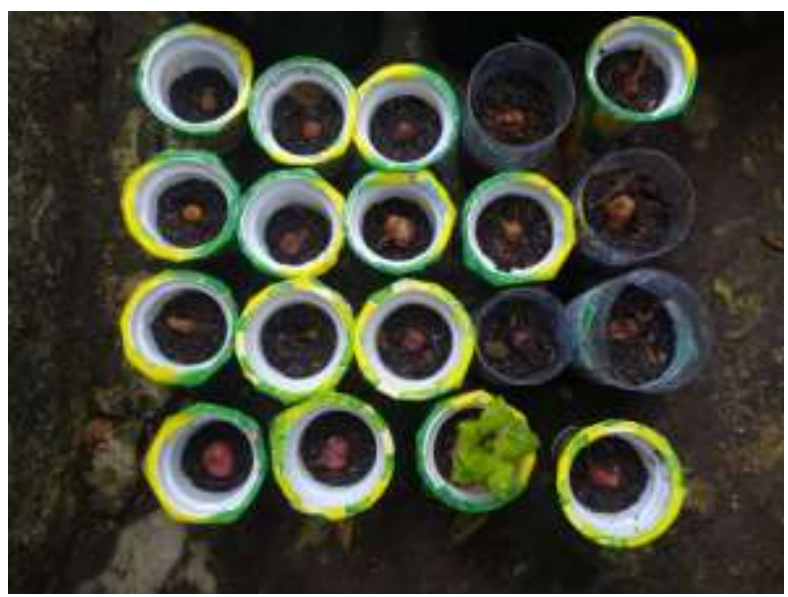

Gambar 12. Kegiatan menanam

Dengan adanya pelaksanakan membaca buku cerita, anak-anak mulai mengenali sejarah Indonesia, daerah, dan keluarganya. Pengenalan diri tersebut semakin diperkuat dengan kegiatan menanam sehingga menumbuhkan karakter mandiri. Hal ini juga nampak dari partisipasi anak-anak mengikuti setiap kegiatan sehingga anak-anak dapat belajar menjadi mandiri dan memahami halhal yang terjadi pada diri mereka sendiri.

Karakter mencoba hal baru, cinta makhluk hidup, kekeluargaan, bertanggung jawab dan mandiri yang muncul pada diri anak merupakan wujud dari tiga unsur penting dari karakter, yaitu pengertian moral, perasaan moral dan tindakan moral. Ketiga unsur ini saling berkaitan dimana nilai dan perasaan moral akan mewujudkan tindakan moral (Ryan dan Lickona dalam Suparno (2015).

Pada kegiatan pengabdian ini, buku cerita bergambar menjadi jembatan dalam pelaksanaan pendidikan karakter yang beriringan dengan unsur pengertian moral. Anak-anak mengetahui nilainilai moral dari nasihat pada cerita yang telah mereka baca. Setelah melakukan kegiatan membaca, anak melakukan refleksi yang merupakan unsur perasaan moral. Berdasarkan kegiatan tersebut, anak melihat apa yang telah mereka lakukan dan menyadari apakah itu merupakan hal yang baik atau hal yang harus diubah. 
Menurut Kesuma (2011), pendidikan karakter yang tertanam pada diri anak memfasilitasi dalam penguatan dan pengembangan nilai yang dapat mewujudkan sebuah perilaku selama proses belajar. Selain itu, karakter dapat mengoreksi perilaku peserta didik yang tidak selaras dengan nilainilai yang ada dan dapat membangun koneksi harmonis antara sekolah,keluarga dan masyarakat dalam mengimplementasikan pendidikan karakter bersama-sama.

\section{SIMPULAN DAN REKOMENDASI}

Kesimpulan dari kegiatan pengabdian masyarakat yang berjudul "Buku Cerita Sebagai Media Pendidikan Karakter Anak di Dusun Temben" ini yaitu: Pertama, anak-anak dapat menumbuhkan karakter berani mencoba hal baru. Hal tersebut dapat dilihat dari partisipasi anak-anak dengan mengikuti setiap kegiatan yang sudah dirancang oleh pelaksana program dengan semangat, yaitu membaca dan menulis cerita pendek, membuat poster terkait dengan kesehatan, dan melakukan kegiatan membuat handsanitizer secara mandiri. Kegiatan dilaksanakan secara menarik sehingga anak juga menjadi bersemangat dalam mengikuti kegiatan yang dilakukan. Selain itu, respon yang diberikan oleh anak ketika berefleksi bersama adalah munculnya keinginan untuk berkegiatan mengenai hal yang baru.

Kedua, anak-anak dapat menumbuhkan karakter cinta terhadap makhluk hidup. Hal tersebut dapat dilihat dari partisipasi anak-anak dengan mengikuti setiap kegiatan menanam tanaman dan literasi serta menonton film bersama yang sudah dirancang oleh pelaksana program dengan semangat. Berdasarkan refleksi yang anak-anak sampaikan, mereka merasa semakin menghargai tanaman dan hewan di sekitar mereka.

Ketiga, anak-anak dapat menumbuhkan karakter kekeluargaan. Karakter tersebut terlihat dari partisipasi anak-anak mengikuti kegiatan menanam dan literasi dengan membuat cerita pendek tentang sejarah dasar. Berdasarkan refleksi yang dilakukan anak-anak, muncul perasaan ingin membantu dan bekerja sama dalam lingkungan keluarga. Keinginan membantu ini dilihat dari sikap mereka yang mulai membantu pekerjaan rumah tangga yang sederhana.

Keempat, anak-anak dapat menumbuhkan karakter bertanggung jawab terlihat dari partisipasi anak-anak mengikuti kegiatan mendongeng dan pembuatan video mendongeng fabel. Selain itu, anak-anak juga mengikuti kegiatan lokakarya protokol kesehatan dengan mencuci tangan yang benar. Berdasarkan refleksi yang diungkapkan anak-anak, muncullah tanggung jawab untuk menjaga kebersihan diri dan lingkungan demi kesehatan bersama.

Kelima, anak-anak dapat menumbuhkan karakter mandiri dan mengenal diri sendiri terlihat dari partisipasi anak-anak mengikuti setiap kegiatan membaca buku mengenai sejarah dan menanam rimpang. Pada kegiatan refleksi, anak-anak merasa dapat belajar menjadi mandiri dan memahami halhal yang terjadi pada diri mereka sendiri.

Rekomendasi pada kegiatan pengabdian ini adalah 1) Pengabdi perlu memastikan jaringan internet dengan stabil, sehingga dapat mendukung kegiatan secara daring, 2) Pengabdi perlu melakukan pendekatan kepada anak agar anak lebih mudah mengikuti kegiatan yang diberikan, 3) Pengabdi perlu memberikan jadwal kedatangan anak-anak agar teratur dan tetap mematuhi anjuran pada masa PPKM.

\section{UCAPAN TERMAKASIH}

Kami mengucapkan terima kasih atas bantuan dan dukungan dari:

1. Lembaga Penelitian dan Pengabdian, Universitas Sanata Dharma

2. Warga Dusun Temben, Desa Ngentakrejo, Kecamatan Lendah, Kabupaten Kulon Progo

\section{DAFTAR PUSTAKA}

Kesuma, D. (2011). Pendidikan karakter kajian teori dan praktek di sekolah. Bandung: Remaja Rosdakarya.

Kesuma, D., Triatna, C., \& Permana, H. J. (2011). Pendidikan karakter: Kajian teori dan praktik di sekolah. Bandung: Remaja Rosdakarya.

Kurniawan, S. (2013). Pendidikan karakter: Konsepsi \& implementasinya secara terpadu di lingkungan keluarga, sekolah, perguruan tinggi, dan masyarakat. Yogyakarta: Ar-Ruzz Media.

Maunah, B. (2015). Implementasi pendidikan karakter dalam pembentukan kepribadian holistik siswa. Jurnal Pendidikan Karakter. $V(1)$. 90-101.

Mitchell, D. (2003). Children's literature, an invitation to the world. Boston: Ablongman.

Nur, M. R., (2020). Tantangan pendidikan karakter di masa pandemi. [Online]. [Diakses tanggal 28 Januari 2021]. Diambil dari https://aceh. tribunnews.com/2020/10/09/tantangan-pendidikan-karakter-di-masa-pandemi

Nurgiyantoro, B. (2016). Sastra anak: Pengantar pemahaman dunia anak. Yogyakarta: Gadjah Mada University Press.

Suparno, P. (2015). Pendidikan karakter di sekolah. Yogyakarta: Kanisius. 
Wardana, G. K., (2020). Nasib pendidikan karakter di masa pandemi. [Online]. [Diakses tanggal 28 Januari 2021]. Diambil dari https://kumparan. com/gilang-kusuma-wardana/nasib-pendidikan-karakter-di-masa-pandemi-1u0aEcfffJ6/full
Wibowo, A. (2013). Pendidikan karakter berbasis sastra: Internalisasi nilai-nilai karakter melalui pengajaran sastra. Yogyakarta: Pustaka Pelajar. 